\title{
The Representation of Local Wisdom in Short Stories: A Study in North Sumatra
}

M. Surip ${ }^{1}$, S. Fahmy Dalimunthe ${ }^{2}$ \& M. Anggie. J. Daulay ${ }^{3}$

1,2,3 Universitas Negeri Medan, Indonesia

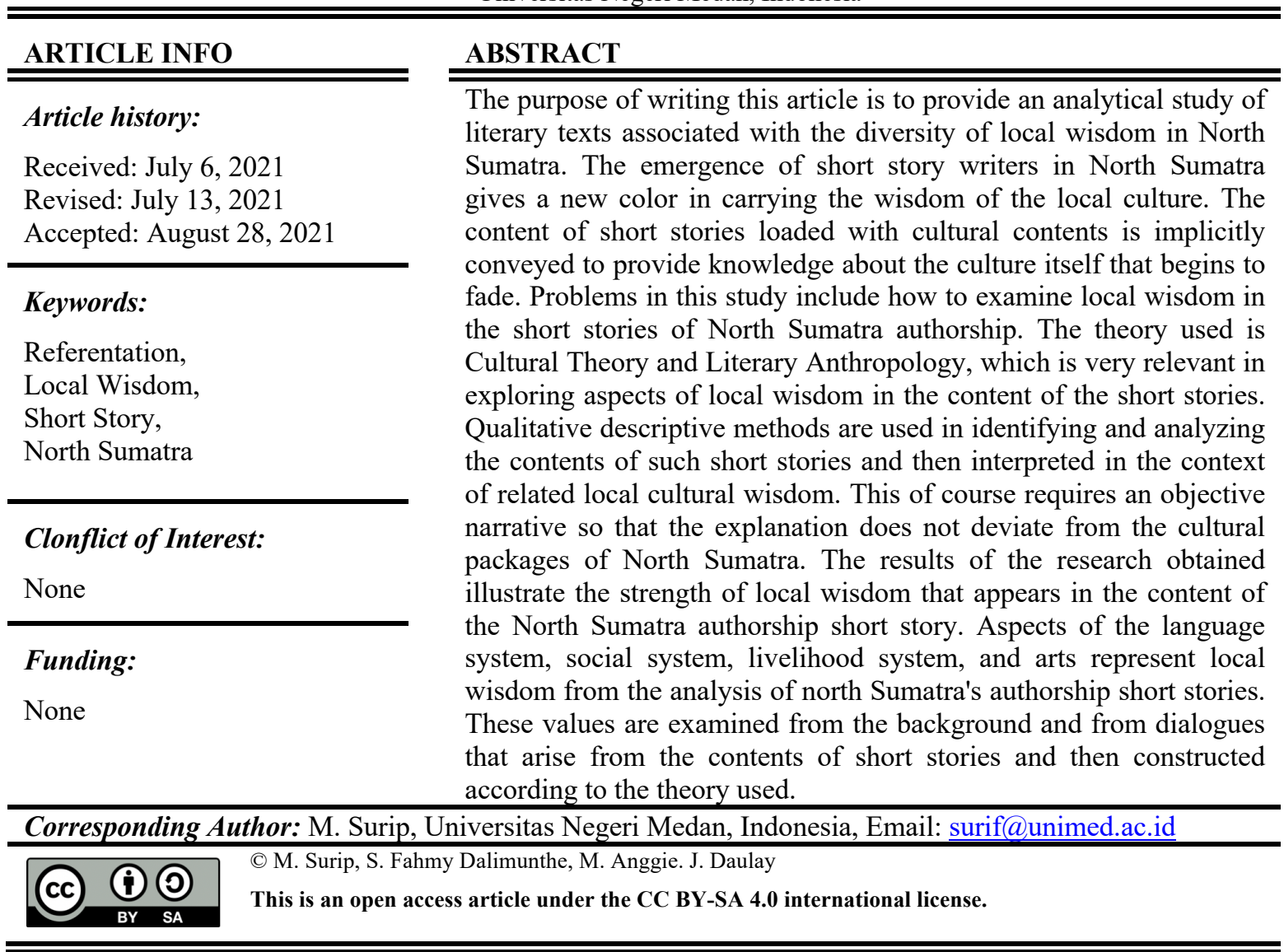

1. Introduction

North Sumatra contributes greatly to Indonesia's literary history. Writers born in North Sumatra have provided evidence of their reliability in finding aesthetics in Indonesian literary works. Merari Siregar, Sanusi pane, Amir Hamzah, Armijn Pane, and Khairil Anwar are writers who lay the foundation of Indonesian literary aesthetics originating from North Sumatra. Therefore, it takes continuous efforts to string together the development of North Sumatra literature. The battle can be done in one form of activities carried out by critics to monitor the development of North Sumatra literature. As is known, North Sumatra gave birth to many writers who are diligent and consistent with their works, (Irwan, 2010) and (Ahyar, 2012).

The literary activity in North Sumatra is growing with the emergence of many young creative writers. This is seen with the productivity of short story works that are widely published in the mass media, short story anthology books can even be seen from enthusiasm in participating in various short story writing competitions, (Irwan dkk, 2008). The content of the short story is loaded with local cultural, social, and religious contents that become the background of the story so that it looks familiar to the local community and reflects the habits that are often done. Literary works that are a reflection of the author's imagination describe social phenomena that often occur in society. Not surprisingly, aspects of local wisdom are often carried out to highlight the story that occurs. The local wisdom of the content of the short story reflects the cultural conditions of the community that become the guidelines of life early on and are internalized in social entities (Sibarani, 2012) and (Ratna, 2011). Culture becomes the foundation in determining aspects of local wisdom in the content of short stories that appear in the community. These aspects are interesting to interpret by analyzing the short stories of the authors in North Sumatra. 


\section{Literature Review}

Culture is a form of the complexity of knowledge, beliefs, arts, morals, laws, customs, and all other abilities and customs acquired by a person as a member of society, Horton \&Chester (1996: 58). Forms of tradition in a group of people that have philosophical, social, and cultural values become pakem in a social order of society.

Some forms of culture are defined by the Koentjaraningrat, among others, the First form of culture as an idea, idea, value, or norm; Both forms of culture as activities or patterns of human action in society; The third is the form of culture as objects of human works. This form of culture is concrete because it is the material of all human creation, works, actions, activities, or deeds in society $(2009,150-153)$.

Literary works are one form of cultural manifestation of the life of every person or group of people (Anwar, 2012). In literature contains the values of representation of cultured life in the form of human effort, the struggle of each person or group in determining its future. Culture is a directed and planned activity (Van Peursen, 1976:10-11). Literary works always display a picture of life, while life itself is a social reality. Thus, all aspects of human life with its culture are found in literature, including the content of local wisdom that is reflecting the culture of the people, (Damono, 2012: 11).

Etymologically the word local wisdom consists of two words, wisdom and local. Wisdom is defined as a person's ability to behave as a result of an assessment of something, object, work, or event that occurs. While local refers to a dimension of space that occurs social interaction based on the values of wisdom. Sibarani concluded that local wisdom is the wisdom, or original knowledge of a society derived from the noble value of cultural traditions to regulate the order of community life, (Sibarani, 2012: 114).

According to Koentjaraningrat in Tasmuji Et al (2011:160-165) that the elements of culture are universal and can be found in the culture of all nations scattered in various parts of the world. The seven elements of culture are:

a. Language System; Language serves as a means of fulfilling social needs to interact or relate to others, also demonstrating the human ability to build cultural traditions, create an understanding of social phenomena that are revealed symbolically, and pass them on to the next generation.

b. Knowledge System: The knowledge system is more about ideas that include elements used in human life. The knowledge that is abstract and universal must be able to answer the challenges of nature is survival.

c. Social System: Kinship systems and social organizations are a form of a cultural element in understanding how humans shape society through various social groups.

d. Living Equipment Systems and Technology; Human culture based on the technological elements used by a society in the form of objects that are used as living equipment with the form and technology of its time.

e. Living Livelihood System; Focuses on how the livelihood of a group of people or their economic system to meet their needs.

f. Religious System; The function of religion in society is the belief that there is a supernatural or supernatural force that is considered higher than humans and why it performs various ways to communicate and seek relationships with these supernatural forces.

g. Art: The concept of art is related to objects or artifacts that contain elements of art, such as sculptures, carvings, and decorations. Elements of art in human culture lead more to the techniques and processes of making art objects.

\section{Method}

This research uses a qualitative descriptive approach based on the background of the problems that have been presented before. The qualitative approach chosen aims to understand the phenomena of what the subject of the study experiences holistically and describe the phenomenon in the form of words and language, in a special context that is natural by utilizing various scientific methods (Moleong, 2007: 6).

Analysis in this study was conducted using the approach of literary anthropological theory, which in this study examined the structure of the literary text (short story) of North Sumatra authorship and then connected with the concept or context of socio-cultural situations. It also includes it in terms of figures and characterizes 
that describe the behavior and attitudes of figures (characterization) in the literary work to uncover the culture of a particular society, (Endaswara, 2013: 19).

\section{Results and Discussion}

Several literary works in the form of short stories written by North Sumatran writers analyzed refer to the theory of Koentjoroningrat consisting of language systems, knowledge systems, social systems, living equipment systems and technologies, livelihood systems, religious systems, and arts. Some of the short stories were taken into units of analysis in this study.

Table 1. Short story data and his work

\begin{tabular}{clll}
\hline No & \multicolumn{1}{c}{ Author } & & \multicolumn{1}{c}{ Short Story Title } \\
& & & \\
\hline 1 & Aishah Basar & - & Tumin \\
\hline 2 & Dani Sukma & - & Bbdi Seorang Istri \\
& & - & Mengapa ia memilih tinggal di penjara \\
\hline 3 & Riduan Situmorang & - & Putri Lopian \\
\hline 4 & Dian Nungin & - & Dua Penantian \\
& & - & Menggenapi Janji \\
\hline 5 & Sartika Sari & - & Laoh \\
& & - & Malam Mitoni \\
\hline 6 & Siti Maulida Dina & - & Muslihat Ampok \\
& & - & Luka di balik tembut-tembut \\
\hline 7 & M. Ikhsan Ritonga & - & Manyunduti \\
& & - & Martandang \\
& & - & Pelaminan Togar \\
\hline 8 & Radiva Dwika Nurfadilla & - & Penjahit Kesawan \\
& & - & Aksara Membara \\
\hline 9 & Radja Sinaga & - & Mujair di tubuh nauli dainang \\
& & - & Tabib Goklas \\
\hline
\end{tabular}

There are 18 short stories analyzed from the perspective of literary anthropology, where aspects of local wisdom in North Sumatra are the main focus in elaborating the contents of the short stories above. The following will be spelled out an analysis of local wisdom from short story works as research data.

Local Wisdom of North Sumatra Short Story by Aishah Basar

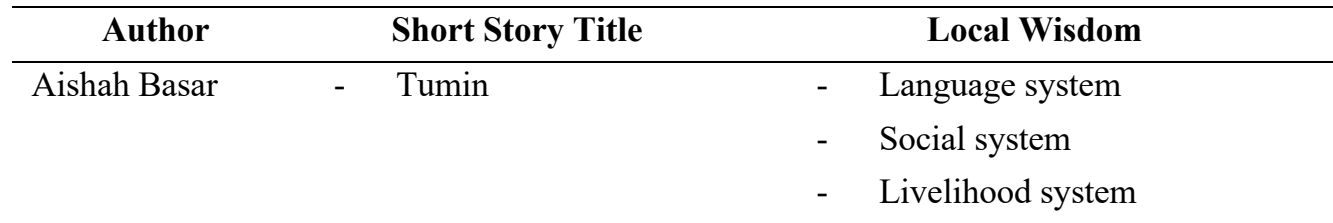

There is a tradition in the city of Barus known as mamogang. Mamogang is done to welcome the fasting month which is precisely two days before Ramadan. This tradition is done by slaughtering and processing buffalo meat. When the buffaloes are herded for slaughter, usually the children who participate will hum. The sound of the sing is as follows.

\section{"Kandilo potang-potang, barisuk kito mamogang,"}

This song is chanted over and over again. Then the buffaloes will be paraded into the river. This is done due to the absence of transportation that can transport buffalo. After the mamogang tradition is completed, there is one tradition that is carried out to welcome the holy month of Ramadan. The second tradition mentioned is found in the following story.

"After enjoying the delicious processed buffalo meat that will also be eaten during the first sahur tomorrow night, Tumin and his friends were invited to go Balimo during the day tomorrow."

Balimo is a tradition of self-cleansing in welcoming Ramadan. People will flock to the headwaters of the Aek Sirahar river while carrying limos. Limo or lime is an herb consisting of pandan masang leaves, patchouli leaves, betawi, sarei, harun sarei, urat usar, lime kesturi or lime purut, and kambelu leaves. This limo will be poured all over the body so that both the river and the community will have limes (Pesurnay, 2018) and (Sumada, 2017). Even this limo tradition is not only done by the Muslim community, but the entire 
community that is there participates. It teaches us that tolerance among religious people must be woven and shared by every human person.

Local Wisdom of North Sumatra Short Story by Dani Sukma

\begin{tabular}{|c|c|c|}
\hline Author & Short Story Title & Local Wisdom \\
\hline \multirow{5}{*}{ Dani Sukma } & \multirow[t]{2}{*}{ Abdi Seorang Istri } & Language system \\
\hline & & Social system \\
\hline & \multirow[t]{3}{*}{ Balada Kampung } & Language system \\
\hline & & Social system \\
\hline & & Livelihood system \\
\hline
\end{tabular}

In the short story Abdi a wife exposes the service of a wife to her husband. In this story his village experienced a natural disaster, this was spurred by heavy rains that never subsided.

“... My God, for the umpteenth time the Deli River narrates flooding. It's not just this time that the people of this area are surrounded by floods, but I feel like the flood this time will sow some kind of disaster."

North Sumatra is closely related to the word "Deli". Deli is a form of sultanate based in the region of North Sumatra. Deli River is one of the eight rivers that flow through North Sumatra. Deli River stretches up to 73 $\mathrm{km}$ and still flows to this day. In addition, this short story also uses the word Uda is one of the words that are usually used between Batak people who are known as partuturan.

"Surau belongs to Uda Parluhur Siregar, a traditional elder in our village. When I got inside the surau, I thought Dorsina was crying with three other children."

The use of the Uda part there are several provisions, namely 1) our call to the younger brother of our father; 2) Our call to men who are in common with us whose hereditary order is on the same level as our father but our father is older than him; 3) Our call to the husband of our mother's younger sister 4) Our call to the husband of our host. This short story also contains the social system that exists in Batak society, where if a Batak married couple does not have a son is considered a disgrace. And usually, they will continue to add offspring until they get the boy. This also became insults and scorn of others and even the Pargaulan family itself towards his wife (Agustina dkk, 2016). Kampung Horas ballad is the next short story from Dani Sukma that raises a background of familiarity with the life of Batak people. Batak tribe is one of the largest tribes in Indonesia that occupies the region of North Sumatra. This short story uses a lot of language systems with the use of terms that are often used by the people of North Sumatra, especially the Batak tribe. Alamak, Bah, Oi, Hajab, Uda, Pulak, Sukak, Umak, Betol which is a variation of the word is often used to highlight the condition of the local speech area.

Local Wisdom of North Sumatra Short Story by Riduan Situmorang

\begin{tabular}{|c|c|c|}
\hline Author & Short Story Title & Local Wisdom \\
\hline \multirow[t]{2}{*}{$\begin{array}{l}\text { Riduan } \\
\text { Situmorang }\end{array}$} & $\begin{array}{l}\text { Mengapa ia memilih tinggal } \\
\text { di penjara }\end{array}$ & $\begin{array}{ll}- & \text { Language system } \\
\text { - } & \text { Social system } \\
\text { - } & \text { Livelihood system } \\
\text { - } & \text { Art system }\end{array}$ \\
\hline & Putri Lopian & $\begin{array}{ll}\text { - } & \text { Language system } \\
\text { - } & \text { Social system }\end{array}$ \\
\hline
\end{tabular}

The use of regional terms in this short story gives the story its attachment to the area where speech takes place. The words 'pulas' and 'boru' are terms used by Batak people and have certain meanings.

"There is no point in peace but colonized. So, I called for it."

Pulas in the Batak language dictionary is interpreted as useful. Guna-guna is magic, black magic, satanic science, and science of a mystical nature. 'Boru' in Batak is a father's call to his daughter. It is not only interpreted as a call to girls but can be spoken to the sister of a brother, the wife of a brother, a greeting to a woman of the same age with a difference in a surname or related to the father's brother. This boru is a clan designation for women. This short story also includes a religious system in which two beliefs namely Christianity and Islam become local content in the conflict that occurs.

"Apparently, Aceh and Nomensen worship different Allahs." 
The short story quotes show the difference in trust between Nomensen and Aceh. Nomensen converted to Christianity and brought the religion to the Batak area and had the aim to build the kingdom of God in the land of Batak. While Aceh adheres to Islam and is a friend of Sisingamangaraja XII because he had studied in Aceh, (Sibarani, 2012). However, the God who worships the two has differences. Christians who worship Allah while Aceh who worship Allah SWT. The terms used in the short story of the lopian princess also can not be separated from the call commonly used Batak tribe such as the word datu which is interpreted in the Batak language dictionary is shaman. Pariban is interpreted as a cousin in Batak kinship. Cousins in this kinship are divided into two, female cousins of Bone's daughter or male cousins from Namboru. In Batak custom, the expression pariban occurs because of the relationship between men and women which if the boru of the woman is the same as the boru of the man's mother if from the aspect of the male view. But unlike the view of women, pariban is a cousin born to Namboru or who is in the same room with the woman's father. So it has become the customary law for Batak men and women married to paribannya.

Local Wisdom of North Sumatra Short Story by Dian Nangin

\begin{tabular}{|c|c|c|}
\hline Author & Short Story Title & Local Wisdom \\
\hline \multirow{3}{*}{ Dian Nangin } & Dua Penantian & - $\quad$ Language system \\
\hline & & - $\quad$ Social system \\
\hline & Menggenapi Janji & $\begin{array}{ll}\text { - } & \text { Language system } \\
\text { - } & \text { Social system }\end{array}$ \\
\hline
\end{tabular}

The Karo tribe in the short story Two Waits raises a tradition called nengget. The heads of families who inhabit in siwaluh jabu, which is the traditional house typical of the Karo tribe, often conduct deliberation. Similarly, with this nengget tardisi, where when preparing a plan that has been expected, offered in the house to stay awake and sustainable from the target that wants to be targeted. The promise of lifting the Batak tradition has a patrimonial system, namely the lineage passed down from a man to his son so that many people welcome male offspring. This makes boys look more valuable than girls. To compensate for this tradition was born a sinamot tradition that shows that girls also have valuable value in Batak society as well. Sinamot is a dowry that must be paid by men if they want to be married from the Batak tribe. Many of the conflicts that arise are related to sinamot in the short story Two Waits where the number of inappropriate dowries creates intrigue between the two families. Women who have a higher education as well as a good job, make the sinamot attached to it more expensive. The negotiation process between the two sides is known as marhata sinamot which is a process of meeting between the families of the two parties that discusses the amount of money that must be spent on the women's side, (Priyadi dkk, 2013). This transaction is in the form of a fee or price purchased by paranak (male parties) to parboru (girls). Marhata sinamot is not only influenced by the girl but from the male side is also involved. It covers his social status, occupation, education, his family's social standing.

Local Wisdom of North Sumatra Short Story by Sartika Sari

\begin{tabular}{|c|c|c|}
\hline Author & Short Story Title & Local Wisdom \\
\hline & Laoh & - $\quad$ Language system \\
\hline \multirow[t]{5}{*}{ Sartika Sari } & & - $\quad$ Livelihood system \\
\hline & Malam Mitoni & - $\quad$ Language system \\
\hline & & - $\quad$ Social system \\
\hline & & $\begin{array}{l}\text { - Living equipment systems and } \\
\text { technology }\end{array}$ \\
\hline & & - $\quad$ Livelihood system \\
\hline
\end{tabular}

Javanese culture is very attached to the short story Laoh which took the time of Dutch colonization. The term tandil, porter, forced labor gives a picture of a tradition of colonialism that utilized the energy of the local population in working on dutch government plantations.

"Just like the previous days and hours, kebon was already filled with porters."

The above short story quote explains that in the Dutch colonial period, the livelihood system of the Indonesian people was as Kuli. Porters are people who work using physical strength. So that the Dutch colonial uses the energy or physical strength of the people in Indonesia. Their work was done tirelessly and it all hurts. Porters were forcibly employed and there was a lot of torture on the workers on the grounds that those who were tortured had been lazing around. In the short story Malam Mitoni by Sartika Sari there is a 
social system in the form of customs from java. This custom is often done by Javanese people when a pregnant woman has entered the age of seven months. This tradition is still carried out by Javanese people even though they have settled in North Sumatra. Mitoni is a series of ceremonies about the life cycle that is still used in Javanese society (Rahyono, 2019). This mitoni ceremony is a custom that is carried out during pregnancy with a gestational age of seven months. The purpose of this mitoni tradition is that the embryo in the womb and the mother who contains always get salvation. In Javanese customs, if a pregnant woman has entered the seven-month gestational age, there will be a customary process that must be passed. It is included in the traditional Javanese tradition that people usually call the Seven Monthly.

Local Wisdom of North Sumatra Short Story by Siti Maulida Dina

\begin{tabular}{clll}
\hline Author & \multicolumn{1}{c}{ Short Story Title } & \multicolumn{1}{c}{ Local Wisdom } \\
\hline \multirow{3}{*}{$\begin{array}{c}\text { Siti Maulida } \\
\text { Dina }\end{array}$} & Muslihat Ampok & - & Language system \\
& & - & Livelihood system \\
\cline { 2 - 4 } & & - & Art system \\
\cline { 2 - 4 } & Luka di balik tembut-tembut & - & Language system \\
& & - & Art system
\end{tabular}

Muslihat Ampok is one of Siti Maulida Dina's short stories. Ampok is the name of a bird in batak language. Ampok bird is a fictional character created by the author who describes the emotional relationships between the characters in it. This ampok bird is often told every si Gale-Gale dance music is covered. Si Gale-gale is a wooden statue used during the ritual burial of corpses in the Batak tribe. This statue is played by someone using hidden ropes. Originally, this ceremony was only for people who died without having children or died when all their descendants had died earlier than him. If the deceased person has a high position like a king or elder, it will be a disgrace for him with his departure without having a successor or descendants. So that Gale-gale is intended to continue his descendants in the afterlife (Rahyono, 2019).

Short story Wounds Behind Tembut-tembut background karo tribal community. Tembut-tembut is a mask or known as a mask Tembut-tembut Seberaya.

"Ah, this woman who has become your best friend broke my daydreams about your stories about the long-standing tembut in the corner of the kitchen. As you say at night, these tembuts are made for gundala-gundala dance masks. Someday, I'll use it with friends as a cultural successor..."

This mask was used as a rain-calling ritual that was first performed in Seberaya Village. Originally, the mask was invented in the 1910s by Pirei Sembiring Depari and only his family can use it. This mask is used as entertainment for the community. After the dance is over, it always rains. Since then, the Tembut-tembut mask has become a tool in gundala-gundala dances. This Gundala-gundala dance will be a ritual or ceremony calling rain referred to as Ndilo Wari Udan.

Local Wisdom of North Sumatra Short Story by M. Ikhsan Ritonga

\begin{tabular}{clll}
\hline Author & \multicolumn{1}{c}{ Short Story Title } & & \multicolumn{1}{c}{ Local Wisdom } \\
\hline & Manyunduti & - & Language system \\
& & - & Social system \\
& & - & Livelihood system \\
\cline { 2 - 4 } M. Ikhsan & Pelaminan Togar & - & Language system \\
Ritonga & & - & Livelihood system \\
& & - & Art system
\end{tabular}

Muhammad Ikhsan Ritonga was epic in displaying local cargo from North Sumatra in his work. The term manyunduti itself is a cousin marriage conducted by the Batak Angkola or Mandailing community. This marriage must take place in the Batak Angkola custom on the grounds of insanity in choosing a life partner and strengthening relationships between families. There is the next term of Batak Angkola language, namely bagas godang which means a happy home. So, in the wedding of the Batak Angkola tribe, the house that contained an event is referred to as bagas godang. Manyunduti by Muhammad Ikhsan Ritonga there is a social system that is kinship.

"Zairana, isn't that your namboru child." 
In Batak tribal custom it is explained that the namboru child is the son of the father's brother or sister, and can marry the daughter of a brother. This relationship is called pariban. The relationship is not always from the siblings of the father or mother. The purpose of the marriage relationship is so that the fraternal rope with the bones (brothers) is closer. In this case, the greeting of Bone in question is the brother-in-law of his father's brother or a genealogy far from the brotherhood, (Sibarani, 2012). In the social context of Batak Angkola community help each other in preparing the wedding party of neighbors who are close to the house.

"At weddings held in the village, the people always carry royong to prepare food to people who will carry out the wedding in their homes. Like his sister from Zairana. Villagers flocked in the morning in preparation for the feast."

The short story quote describes the sense of concern of the people in the village as higher than the people in the city. People who are in the village are more participatory towards people who have a prayer or event both joy and sorrow. In the short story of Togar By Muhammad Ikhsan Ritonga there is art in the form of musical art. It is found in the marriage that will be carried out using the customary process of the Angkola and Mandailing tribes.

"Lahma, for the reception we use Mandailing ornaments and gordang while the child..."

The quote introduces the day-to-day gordang. Gordang part-time is a musical art from Tapanuli in the South and the art is commonly used at party events from Batak culture, especially Angkola and Mandailing.

At the wedding of the Angkola and Mandailing tribes, there is also decorative art known as sopo ijuk. Sopo ijuk is interpreted as an ijuk-roofed hut as a form of reflection in mandailing custom.

"Yes, it must be ma'am, because this we take from the original place directly. Sopo ijuk in Sibanggor. Moreover, plus the miniature moon above. It's getting better and brighter."

In addition, there are four colors of the greatness of the Mandailing people that are always in the fabric. The color has a different meaning, of course. The four-color flag is called the siararabe flag, a flag that has a length of 7 meters and a width of $54 \mathrm{~cm}$ with red, black, white, and yellow. These colors are rectangular and made into intersoress. The location of the color in this interspersing hose depicts the situan na jaji (many masters) in the kingdom. And those four colors have become solid in the flag, (Pesurnay, 2018).

Local Wisdom of North Sumatra Short Story by Radiva Dwika Nurfadilla

\begin{tabular}{clll}
\hline \multicolumn{1}{c}{ Author } & \multicolumn{2}{c}{ Short Story Title } & \multicolumn{1}{c}{ Local Wisdom } \\
\hline \multirow{2}{*}{$\begin{array}{c}\text { Radiva Dwika } \\
\text { Nurfadilla }\end{array}$} & Aksara Membara & - & Language system \\
& & - & Social system \\
\cline { 2 - 4 } & & - & Livelihood system \\
\cline { 2 - 4 } & Penjahit Kesawan & - & Language system \\
& & - & Livelihood system \\
& & - & Religious system
\end{tabular}

The short story of The Burning Script by Radiva Dwika Nurfadilla contains a system of knowledge about history related to the area of Medan. Aksara tax is part of the history of spending in the city of Medan.

"The fire was a very heartbreaking event for many people who hung their lives there. Aksara tax is a fairly legendary tax in Medan city. It's been around since the 90s. But now the Aksara Tax is only a memory."

The Script Tax has a history in which people look for work and depend on their lives in that place. The tax that existed in the 90s had to be flattened to the ground by the tragedy of a fire that scorched one of the iconic shopping centers in the city of Medan.

In addition, the content of the short story is also loaded with the belief system that is embraced, namely the religion of Islam. There is a dialogue that contains the mention of the name of Allah SWT and the Shari'ah that must be done by Muslims.

"The dawn Azan resounded, Wak Izah left the shop, rushed to take wudu and perform the dawn prayer. While Kak Ira and Kak Suci are still busy showings off their wealth." 
Islam has an obligation to pray five times a day a night. The first prayer is dawn. Then the Dawn azan is a matter to inform that the time of prayer has arrived. Prayer is a priority that must take precedence when the time has come. This is the way Muslims ask the Khalik, Allah SWT.

In the short story, Kesawan Tailor also still highlights the historical sites of the city of Medan, where Kesawan is a city that became the center of the economy from the Dutch colonial era to the present day (Sibarani, 2012). Kesawan is particularly famous for its textile shopping malls and dozens of tailors who hang on to life from taking customer stitching orders.

"Olah is sewing of one of the shophouses in the cloudy area. The shophouse that has been established for twenty-three years is the legacy of his late parents."

In addition, the contents of short stories also give rise to myths related to the prohibition of sewing clothes while pregnant. It is said that this can result in the child who will be born into a cleft.

"That's not it, Olah. We can't sew when we're pregnant. He said his son could be cleft.

Look at the shophouse that Ica was temporarily closed. As long as she's pregnant."

Of course, this myth becomes a tradition that is hereditary and unconsciously internalized in society. The social condition of people who believe in supernatural things causes a lot of challenges that occur in response to traditions that have been going on for a long time.

Local Wisdom of North Sumatra Short Story by Radja Sinaga

\begin{tabular}{|c|c|c|}
\hline Author & Short Story Title & Local Wisdom \\
\hline \multirow[t]{5}{*}{ Radja Sinaga } & Mujair di tubuh & Language system \\
\hline & nauli dainang & Social system \\
\hline & & Livelihood system \\
\hline & Tabib Goklas & Language system \\
\hline & & Religious system \\
\hline
\end{tabular}

Radja Sinaga raised a story about the life of the Batak people in his short story entitled Mujair in Nauli Dainang's Body. The short story uses Tomok as the setting for the story. The background of this place is one of the villages located on the east coast of Samosir Island. Nauli Dainang itself is the name of the bolhom ferry.

“... The ship is not difficult to trace from Tomok Port, just look at the side of the ship inscribed With Nauli Dainang and at the helm of the ship just above the steering room, fluttering the Red-White-Black flag adjoining the Red and White. He will be there all night after going back and forth from Samosir-Parapat."

The phrase is Batak Toba language which means Nauli means beautiful or beautiful and Dainang means Mother. When these two words are interpreted to be "Beautiful Mother". In addition to the name of the ship, the bolhom ship also has another attraction, namely two flags. Both flags are red-and-white and red-andwhite. These two flags have their own meaning where the Red-White-Black Flag is the flag of the Batak tribe.

Based on Batak customs, the color in the flag has the same definition as Ruma Gorga color or often called Ruma Bolon. Ruma Bolon is a typical Batak traditional house. Black symbolizes hahomion i.e. leadership, red symbolizes hagogoon i.e. spirit or strength, and white symbolizes habonaron i.e. holiness or truth. Then there is a second flag that symbolizes the National Flag of Indonesia. This flag is usually used as a form of love for the homeland and the identity of the owner of the ship. This aims to inform foreign tourists that the area is still Indonesian territory. In social interaction in Batak community, tuak is an interacting media where this tuak becomes a mandatory drink when citizens, especially men gather and sing in lapo tuak (tuak shop).

"At first he did not bother, still actively looking at the ship of his father's relics, until gradually he felt odd. Every day of work, the profits never run out even though the pots of the levers. To gamble, he never thought, even though he understood to play."

Tuak is one of Batak's signature drinks in the form of wine or alcoholic beverages produced from fermaentasi nira. Tuak is often presented in important events to entertain guests or consumed daily as a body warmer. The taste of tuak is also inseparable from the origin of the region and the maker. So it is not surprising that the taste of tuak on some lapo tuak has a different peculiarity. This tuak drink is often used as a livelihood because it requires expertise in processing it (Agustina dkk, 2016). The short story of Tabib Goklas uses the Batak tribe as the identity of the characters in the story. So there is a lot of use of genealogy speech that appears in the contents of the short story. 
"Here, feed this orange stomach in host husband," said Goklas steadily.

"At the very least, this amang money is to buy the lime."

There are three speeches in the above quote, namely the host, amang, and opung. In Batak, these three things are called partututran. The three parts have different functions and meanings. It is influenced by the kinship system, gender, and age. The host is the name of a mother. While Amang is called a father. Lastly there is the word opung / ompu or ompung (pronounced: oppu / oppung) which means grandfather.

Batak tribe is one of the tribes that greatly maintain its culture by sticking to traditions and customs. A physician is someone who has a profession that can cure patients metaphysically. This profession has been passed down through generations trusted by the community and the healer himself has higher strata in the community.

"You might be asking who Goklas is, right? Like this, Goklas is touted as a healer in our village. "If you need someone to treat a chronic disease that doesn't heal, come to the physician Goklas!"

This tradition continues to survive especially non-medical treatments that cannot be cured by doctors. The ways that are done are sometimes irrational but still, this healer is considered able to cure chronic diseases that never heal.

\section{Conclusuion}

From the results of short story analysis that has been summarized before, it is seen that local wisdom that often appears is the language system, social system, livelihood system, religious system and art system. This shows that the writers of North Sumatra short stories give rise to traditions that are still inherent in the community. In addition to providing the inherent imagination power to the reader, it is expected that cultural related things that are considered to have faded will reappear so that it does not disappear in people's memories. The existence of these locally charged short stories gives an enlightenment to readers who before did not know the socio-cultural conditions in North Sumatra. The hope is that more young authors of short stories emerge that create beautiful works of wisdom so that the preservation of existing and forgotten cultures can be excavated and preserved in a work of writing.

\section{References}

Abdullah, Irwan. 2010. Konstruksi dan Reproduksi Kebudayaan. Yogyakarta: Pustaka Pelajar.

Adullah, Irwan, dkk. Ed. 2008. Agama dan Kearifan Lokal dalam Tantangan Global. Yogyakarta: Pustaka Pelajar.

Agustina, Syahrul.R, Asri, Yasnur. 2016. "Local Wisdom in The Modern Short Stories By Minangkabau". Humanus. XV. 1. 14-31

Al-Makruf, Ali Imron, dkk. 2017. Pengkajian Sastra Teori dan Aplikasi. Surakarta. Djiwa Amarta Press.

Anwar, Ahyar. 2012. Teori Sosial Sastra. Yogyakarta: Ombak

Damono, Sapadi Djoko.2012. Sosiologi sastra. Jakarta: Gramedia

Endraswara, Suwardi. 2013. Budi Pekerti dalam Budaya Jawa. Yogyakarta:Anindita

Horton, P. B \& Chester L. H. 1996. Sosiologi. Jakarta: Penerbit Erlangga.

Koentjaraningrat, 2009. Manusia dan Kebudayaan di Indonesia. Jakarta: Djambatan.

Moleong, Lexy J. 2007. Metodologi Penelitian Kualitatif. Bandung: Remaja Rosdakarya

Pesurnay, Althien John. 2018. "Local Wisdom in a New Paradigm: Applying System Theory to the Study of Local Culture in Indonesia”. IOP Conf. Series: Earth and Environmental Science 175.

Priyadi, Sugeng. Mulia, Dini Siswani. 2013. "Unsur-unsur Kearifan Lokal Masyarakat Pesisir Cilacap". Paramita. 23.2, (2013). 156-166

Rahyono, FX .2009. Kearifan Budaya dalam Kata. Jakarta: Wedatama Widyasastra.

Ratna, Nyoman Kutha. 2011. Antropologi Sastra; Peranan Unsur-unsur Kebudayaan dalam Proses Kreatif. Yogyakarta: Pustaka Pelajar.

Sibarani, Robert. 2012. Kearifan lokal, Hakikat, Peran dan Metode Tradisi Lisan. Jakarta Selatan: Asosiasi Tradisi Lisan.

Sumada, I Made. 2017. "Peranan Kearifan Lokal Bali dalam Perspektif Kebijakan Publik”. Jurnal Ilmu Politik dan Komunikasi. VII. 1. 117-125

Tasmuji, dkk. 2011. Ilmu Alamiah Dasar, Ilmu Sosial Dasar, Ilmu Budaya Dasar. Surabaya.IAIN Sunan Ampel Press 